\title{
The Study of the Necessity and Feasibility of Preschool English Education
}

\author{
Ye $\mathrm{Na}^{1, a}$, Yin $\mathrm{Xin}^{2, *}$ \\ ${ }^{1}$ Department of Pre-school Education, Hebei Women's Vocational College, Shijiazhuang, 050091, \\ China \\ 2Department of Nursing, Hebei Women's Vocational College, Shijiazhuang 050091, China \\ ayinxin1016@hotmail.com
}

Keywords:Preschool English Education, Necessity, Feasibility

\begin{abstract}
English as an international language, it has got more and more attention. As a cornerstone of elementary education, early childhood English education has become the focus of attention. Foreign language teaching should begin at doll, the problem of children English education has been the focus in early childhood education and it has not yet reached a consensus. The paper studied and researched on the necessity and feasibility of early childhood English education.
\end{abstract}

\section{Introduction}

Whether the academic education for young children in English how fierce debate, but requires Kindergarten English Teaching parents is increasing, we can see the English as a common language of global communication much attention. We should seriously consider is: how to learn English for young children Location? How to guide our children to actively learn effectively in English? How do children learn English does not affect the catalytic role of their mother tongue? On this theme, educators opinions, some experts believe that early childhood doll whose main task is to master language, there is no ability to learn other languages than the mother tongue. Have children in the end the ability to learn a foreign language? Children learn a foreign language if the interference of mother tongue learning and mastering? Children English teaching is feasible or not? How effective? Here, the author of the work practice of some superficial to talk about their views on these issues [1].

\section{The Feasibility and Necessity of Carrying out English Education in Kindergarten}

The young children have the ability to learn and accept a second language and the implementation of English education in kindergarten is feasible. Psychological research shows that the key to language development is 6 years ago. During this period, if the language of young children good education, to give rich, you can get the right amount of information to stimulate more fully developed. Conversely, if you miss the critical period of language germination growth, more stimulus amount is difficult to reach the level of full development. Studies on the neuro-physiological mechanisms of speech, contemporary show 4-10 years of age is the best age to start learning a foreign language. In the age when young people, the left brain caused aphasia, can rely on to make up for brain function, some older, the left brain damage caused by aphasia cannot remedy this explanation: brain function in childhood has a greater plasticity. Therefore, during this period children are capable of learning a foreign language. Children from 6 years old, their ability to distinguish between them, cognitive ability, intonation and voice generally have begun to degenerate. Japan's leading early childhood experts believe that 0-6 years is the best period of language development, children in this period there is a possibility of forming two or more speech center. If you only accept the best period in the mother tongue of the stimulus, then, outside the central speech center up gradually degenerate. After the children into school age, up hub it has formed a fixed set of control mode, the next time you learn a second language = Language center it is difficult to accept. So, if we can seize the early childhood education for young children a second language, its potential and development are limitless. English is a kind of knowledge and it is in parallel with Chinese, common sense, computing 
courses, teaching in early childhood is able to do. It will not affect the parent language learning, and will not interfere with native speakers to master, on the contrary, relying on up to learn English, and to learn English with native speakers learn together, and both promote each other, it is a bold attempt, which for the kindergarten curriculum reform and construction provides a theoretical and practical basis. Therefore, the teaching of English as a way children learn language, you can try. The idea that early foreign language learning burden will increase, affecting brain development point of view, has been denied by many of our experiment teaching.

Kindergarten English education is conducive to the development of all aspects for children. Children learning English is a positive intellectual activity, language and cognitive development of young children, a significant role in promoting. In young children English teaching, teachers by designing a variety of educational activities, so that children in a relaxed and natural atmosphere actively enjoy learning spoken language, a preliminary sense of language, stimulate children's interest in learning and curiosity for children entering primary school, junior high stage of learning to recognize and read and lay a good foundation. At the same time learning English but also develop children's language skills and communication skills. In addition, children of English language learning is not simply the acquisition of knowledge, as elementary education, he also help children all the basic skills and good personality, cultivate the habit by learning English, children can increase knowledge, broaden their horizons of children At the same time, promote their all-round development of personality. Therefore, the implementation of early childhood education can not only English, but also conducive to the development of children in all aspects [2].

Intelligence is a comprehensive concept, which includes observation, attention, memory, imagination, thinking ability and creativity, experimental teaching mainly in listening, speaking, reading-based, child care only after hear pronunciation teacher to teacher with doctrine, and slowly they will read. This series of process requires children observation, attention, memory and thinking ability to be highly developed in order to grasp the contents of the teacher to teach. If you learn a word or phrase by a number of syllables, such as watermelon, laundry, refrigerator, et al., Children do not have good memory and language skills, but also very difficult to learn. In fact, the English word preschool education for children arouse interest in learning to cultivate a sound personality has an important role through the experiments show. Only in stimulating interest in, children can truly appreciate the fun of learning English, so acquisition of English in the subconscious. Meanwhile, children learn simple everyday conversation and communicate with people, it is actually a self-confidence, which makes children crossed afraid of making mistakes, shy, too proud and other psychological disorders, there will be a greater help them form healthy personality. Early childhood education can make children master the English Language, while obtaining the second cultural information, and gradually form a sense of the phrase a second language, it is an effective way to understand and absorb multiculturalism.

Children English education is the needs of times and the social development. Progressive Era and social beckon a new generation of high-level talent. English is not just an academic, cultural and communication tool, but also an important way the international arena among master English is the era of the all people's requirements, and English education increasingly younger age tend, therefore, early childhood English education is imperative [3].

Children English education is the need of the development for kindergarten. Children English education actually delivers a new educational trends and educational philosophy. Unique and typical content of education and educational thinking determines the diversity of different educational methods. This new attempt to educate teachers is a challenge in itself, help teachers to think from the perspective of multiculturalism, continue to broaden the thinking and improve their quality. More valuable is the Chinese and foreign culture in the teaching of two can complement each other, learn from each other, thereby enhancing the education level of the whole kindergarten. For early English education in kindergarten can improve the reputation of the kindergarten, to obtain certain economic benefits from the fact promote the sustainable and healthy development of kindergarten. 
Most parents expect the kids' English education. Social development so that parents of the children have become increasingly demanding, English nursery education activities undertaken in a certain extent, represents a strong desire of these parents.

\section{The Main Problems to be Solved in Carrying out Children English Education Activities}

The problem of teachers. The problem is that the English Kindergarten Teacher education is the most important obstacles. Mainly in the following aspects: First, the existing kindergarten teaching English level is not high. They lack the necessary language communication ability, pronunciation is also not accurate enough, and it is important that this part of the lack of timely follow-up training of teachers, will certainly affect the quality of education. Second, teachers lack the necessary guidance in English teaching methods, it is difficult to adapt to English teaching real age characteristics of children, carry out teaching without affecting the interest and enthusiasm conditions. Third, it is difficult to find qualified and suitable both English teachers. Normal English majors do not want to teach in kindergarten, children engaged in English education in the community who lack the necessary knowledge of early childhood education. These three issues are the biggest problem in the implementation of early childhood English education in kindergarten encountered, which hindered the expansion of English in kindergarten education activities largely.

The curriculum issue. The curriculum includes courses, also related to textbooks, teaching methods and other issues. Currently on the market to choose textbooks is too complicated, and really suitable for the kindergarten English education materials rarely, and the lack of continuity textbooks, teaching aids for supporting not many. In addition, the teaching method is a problem and children English education should take the class model, and should primarily be in the game, but how to play together in conjunction with the English education, the lack of appropriate theoretical guidance and practical reference [4].

The problem of locale creation. Take advantage of the best of early childhood language development to early second language education, bilingual language key depends on good interpersonal environment. Children in the first few years of life will be able to communicate freely in their mother tongue and others and it is thanks to the natural language environment. Thus, in the second language acquisition process, the creation of context is crucial. However, now truly make people worry. The English education into each environment is a complex process, which requires experienced teachers make a positive and productive efforts. In addition, the lack of home language environment is a serious problem and parents often only pay attention to how children learn, how many would say a word while ignoring the creation of home language environment.

Educational objectives and evaluation criteria. English kindergarten education is to cultivate children's interest in learning foreign languages, to improve the sensitivity of their acceptance of the language, and lay the initial foundation for further study in the future. The contrast does not match that many parents, including public opinion, all of the children expect too much, and it will say a few English words, will sing a few English song as evaluation criteria, knowledge learning objective of education, to Kindergarten great deal of pressure. Some even had to take the yield compromise attitude. Visible, inconsistent educational philosophy has also brought a corresponding contradictions and conflicts.

In addition, the attitude of the government in the education sector, as well as charges of uniform standards phenomena instant success, especially striking is the impact on the creation of the kindergarten English education for children in the community to bring the English institutions. In recent years, the emergence of various forms of children's English education institutions in the community. Constrained by many educational philosophies, operational mechanism, in the course of these educational institutions engaged in English education, more emphasis on English teaching methods of application, such as systemic reactions pedagogy and game teaching method. However, due to the lack of relatively fixed teachers, early childhood education theoretical knowledge and teaching experience, institutional real value and long-term effects do English training remains to be 
seen, but there are a lot of such institutions, to bring a lot of pressure in kindergarten, forcing it to respond as soon as possible to find effective ways and means.

\section{The Implementation of Early Childhood English Education}

The organization form of early childhood English teaching. When the organization of teaching, teachers should pay attention to the front and rear link what they learn. Coherent, new knowledge from the old knowledge gradually extends, because the object we are facing is the child, the child's nature is fun, so that all children English teaching activities should be based on the game as the main form, so that not only consistent with the child 'fun (age characteristics, to meet the aspirations of children to play, but also enable them to play effectively in the process of natural acquisition of English, then what the game means to be used specifically it \$ woven English teaching activities, the songs of some of the words replaced by English speaking, this only increased the interest in learning English, but also so that children breezed mastered the word) Then you can also combine music game to organize teaching activities, so not only can practice English pronunciation. Continuous, etc., and you can feel the music so that children get the United States to experience the rhythm of the music beautiful) again, you can use to organize sports games in English teaching activities, which not only make learning English can be implemented in a relaxed atmosphere, but also help children have some strong action verbs in English, more than talking about some of the more common forms of organization, in addition can also story and riddle. Daily life as the basis for the implementation of English teaching,

The activities evaluation of early childhood English teaching. In evaluating the success of children learning English, we do not just look at baby English expression in the course of. Grasp of vocabulary, but also depends on whether the children's interest in learning English has generated, are you willing to seriously listen to the teacher and peers speak English and in front of the teacher or peers speak English, will take the initiative to sing English songs. Read English songs. Play English games, in short, we should take interest in and understanding of young children learning English as the main criteria for evaluating effectiveness.

\section{Conclusion}

With the accelerated pace of the internationalization of Chinese, English has become an important communication tool and its position increasingly prominent. Younger age has become a trend of English education activities, followed by a "baby English fever" and emerging groups of bilingual kindergarten. In this paper, we studied the necessity and feasibility of early childhood English education, hoping it can play a certain reference on the implementation of young children English education.

\section{References}

[1] X.D. Liu, The problem of children learning a foreign language, J. Educational Research. 44 (2010) 146-147.

[2] L.P.Guo, The early English education in kindergarten, J. Preschool Education. 18(2005) 55-57.

[3] M.Q.Chen, The problems of critical period of language acquisition, J. Primary English Teaching and Research, 32(2012) 189-190.

[4] Z.Y.Li, The English experimental class, J, Preschool Growth, 4(2007) 38-40. 